\title{
The effect of work engagement on nursing caring behavior with burnout as intervening variables (study of nurses at Datoe Binangkang Lolak Regional General Hospital)
}

\author{
Firda Mokodongan \\ Master of Management, Postgraduate Program, Universitas Muhammadiah of \\ Yogyakarta \\ Firdamokodongan98@gmail.com \\ Heru Kurnianto Tjahjono \\ Master of Management, Postgraduate Program, Universitas Muhammadiah of \\ Yogyakarta \\ herukurnanto@umy.ac.id \\ Nuryakin \\ Master of Management, Postgraduate Program, Universitas Muhammadiah of \\ Yogyakarta \\ nuryakin@umy.ac.id
}

Received: Augustus, 2020; Accepted: September, 2021; Published:

September, 2021

DOI: https://doi.org/10.24123/imb.v20i2

\begin{abstract}
Nurse caring behavior is the core of nursing where nurses must be respectful and responsive to patient preferences, values and needs. Caring behavior is influenced by several factors, including workload, lack of time, and burnout. A nurse with a high tendency to burnout will experience loss of motivation, burnout and affect work professionalism, especially on the caring behavior of nurses to patients. This study aims to analyze the effect of work engagement on nurses' caring behavior with burnout as an intervening variable. This research used quantitative with cross sectional approach. The number of samples in this study amounted to 74 nurses. The sampling technique used in this study was purposive sampling. The research instrument used was a questionnaire. The analysis used is path analysis Ghozali (2016). The result of statistical test of work engagement variable with burnout on nurses has a significant effect in a negative direction. In addition, work engagement with nurses' caring behavior has a significant effect in a positive direction. Meanwhile, burnout with nurse caring behavior has a significant effect in a negative direction. The sobel test results show the effect of work engagement on nurses' caring behavior with burnout as an intervening variable.
\end{abstract}

Keywords: Work Engagement, Nurse Caring Behavior, Burnout. 


\begin{abstract}
Abstrak
Perilaku caring perawat merupakan inti dari keperawatan dimana perawat harus bersikap hormat dan responsif terhadap preferensi, nilai dan kebutuhan pasien. Perilaku caring dipengaruhi beberapa faktor diantaranya beban kerja, kekurangan waktu, dan burnout. Seorang perawat dengan kecenderungan burnout yang tinggi akan mengalami kehilangan motivasi, kejenuhan dan mempengaruhi profesionalisme kerja terutama terhadap perilaku caring perawat kepada pasien. penelitian ini bertujuan untuk menganalisis pengaruh work engagement pada perilaku caring perawat dengan burnout sebagai variabel intervening. Penelitian ini menggunakan kuantitatif dengan pendekatan cross sectional. Jumlah sampel pada penelitian ini berjumlah 74 perawat. Teknik pengambilan sampel yang digunakan pada penelitian ini menggunakan purposive sampling. Instrument penelitian yang digunakan adalah kuesioner. Analisis yang digunakan adalah Path Analysis Ghozali (2016). Hasil uji statistik variabel work engagement dengan burnout pada perawat berpengaruh signifikan dengan arah yang negatif. Selain itu work engagement dengan perilaku caring perawat berpengaruh signifikan dengan arah positif. Sedangkan burnout dengan perilaku caring perawat berpengaruh signifikan dengan arah negatif. Adapun hasil uji sobel terdapat pengaruh work engagement pada perilaku caring perawat dengan burnout sebagai variabel intervening.
\end{abstract}

Kata kunci: Work Engagement, Perilaku Caring Perawat, Burnout.

\title{
INTRODUCTION
}

The role of nurses is very influential in improving the quality of service in the hospital, especially the caring behavior shown in the interpersonal relationship between nurses and patients in the form of attention, and interventions that are useful for maintaining patient health as well as providing positive energy to patients. This is a form of professional nurse service to patients and can also help build a good image of a health service institution in the eyes of the community.

Caring behavior is a characteristic of caring that is beneficial for the well-being of patients, such as sensitivity, attentive listening, comforting, honesty, and patient acceptance without judgment. Nightingale et al. (2018). In addition to nursing services, there are often complaints in the community, especially the caring behavior of nurses and also the ability of nurses to provide services, both nursing care given to patients, where patient dissatisfaction, disappointment and lack of patient trust in nurses often arise. The nurse is not there to serve, but seems to be completing the task.

In Tiara's research (2017) it shows that a caring service from nurses provided to patients where the most assessed low was 54 respondents 
(56.3\%) while the caring behavior assessment of nurses in the high category was 42 respondents (43.8). It is necessary to do a serious followup considering that caring behavior plays a very important role in the patient's recovery process, which estimates that memperkirakan health service is caring while $1 / 4$ is curing. So that in providing care, it is very important to have work engagement between health workers where people depend on health workers, in this case it is related to their life and death Vaksalla (2015).

Work engagement is important to be cultivated in every health worker, especially nurses, because nurses who are bound will have a high sense of the hospital where they work. Work attachments have a positive impact, to fulfill work related to a state of mind in which employees consider themselves to have the ability to cope well with the demands of a job in a job at the workplace Kotze, M. (2018). In addition, the concept of work linkage related to nurses shows that work linkages of nurses can increase infectious personal initiative, reduce hospital mortality and significantly higher financial profitability in the organization Bhatti et al. (2018). Nurses are required to provide professional services to patients. Jalilian et al. (2019) nursing is one of the high stress jobs so that nurses experience stress and fatigue.

Research by Sunaryo et al. (2017) showed that there was a negative relationship between burnout and nurse caring behavior. So it is important to understand well about the proper approach to dealing with burnout, and still with interventions and strategies to build quality care for patients. Burnout is an intervening variable that can connect work engagement to nurses' caring behavior. Research on work engagement, nurse caring behavior and Burnout is very interesting to be used as research because currently not many have researched work engagement in an academic literature. In fact, there has not been much attention to work engagement on caring behavior with burnout as an intervening variable in the scope of human resources in the health environment, especially in hospitals and clinics in the North Sulawesi region in particular.

Based on observations at Datoe Binangkang Lolak Regional Hospital, there is still a lack of work engagement between health care providers and hospitals where there are health workers who look less enthusiastic and also excited when they want to do their work because the workload they face and feel in their daily lives there is no significant change and is impressed. the nurse is only there to complete the task. In addition, health care applies a pattern of coming, where when completing tasks that have been given by the hospital and then go home just like that, so that employees feel less attached to the hospital and less loyal to the hospital, so problems like this if left unchecked will be able to hamper hospitals at the time providing quality care to patients.

Work engagement is something that becomes positive in work related to the mind experiencing enthusiasm, dedication, and absorption. Rai et al. (2017). So that it is very important for every employee, especially 
health workers to be more enthusiastic and think positively in carrying out their duties and responsibilities in providing health services to patients Santhanam (2019). Employee engagement has become a focus because work engagement has an important role in improving a number of organizational outcomes Kotze, M. (2018). In this case, employee engagement can retain employees. Tusa'diah et al. (2017). Meanwhile, work attractiveness is multi-dimensional which can build motivation. Thus, if the workforce engagement of health workers is high, it will have a positive impact on health services at Rai et al. (2017).

Burnout is emotional exhaustion, depersonalization, so it reduces personal achievement. This can occur in individuals who work with people in some capacities Sunaryo et al. (2017). Concerning burnout beware as a serious psychological phenomenon that can lead to higher rates of depression, somatic complaints, and even suicide. Burnout is associated with an increased risk of absenteeism, absence from work due to illness, inability to work and low job satisfaction, as well as individuals who are very likely to be exposed to things where they think about giving up on work. It is this that causes burnout syringe in the nursing profession for several reasons being that nursing, a health care professional, is associated with increasing levels of Sunaryo et al. (2017).

General Caring behavior is an ability to be dedicated to others, watchful supervision, feelings of empathy for others and feelings of love or affection for Tiara (2017). The factors that influence caring behavior, namely lack of time, lack of support, assignments, increased workload, lack of resources, lack of care, emotional divestment, indifference to one another, and peer support Enns (2016).

Research conducted by Zoraya et al. (2019) showed that work attachment to burnout in dentists was obtained at a significant level where there was an effect of work attachment to burnout in dentists in a negative direction. Other research conducted by Salmela (2018) shows that Burnout has a negative effect on work attachments. Further research research by Silver et al. (2018) who show that awareness is positively related to empathy and work attachment and a negative relationship with burnout. Then research conducted by Balasubramanian (2017) shows that work engagement is negative towards burnout.

Research conducted by Han et al. (2018) which shows that work engagement has a direct and indirect effect in improving service delivery by nurses to patients. Other research conducted by Vaksalla (2015) shows that nurses have a relatively high level of expectation, personal growth initiatives, meaning in life and work attachments are significantly correlated. Furthermore, Czerw's research (2015) shows that there is a significant influence between attitudes and work attachments. Then the research conducted by Shantz et al. (2016) which shows that nurse work engagement is closely related to the quality of care and safety compared to administrative support staff. 
Research conducted by Sunaryo et al. (2017) showed that there was a negative effect of burnout on caring behavior. This happens because burnout increases due to fatigue. Another study conducted by Kaur et al. (2013) showed that burnout has an effect on caring behavior. Furthermore, the research of Sondenaa et al. (2015) showed that nursing staff in caring services had a significant relationship with burnout. Then research conducted by Lampert (2017) Burnout has a significant effect on caring.

H1: Work Engagement has a significant effect on Burnout

H2: Work Engagement has a significant effect on Nurse Caring Behavior

H3: Burnout has a significant effect on Nurse Caring Behavior

H4: Work Engagement has a significant effect on Nurse Caring Behavior with Burnout as an Intervening variable

\section{RESEARCH METHOD}

This type of research used in this research is to use quantitative research types. This study uses path analysis with a cross sectional design, so that the research is carried out at a certain time or over a short period of time.

The sample in this study were 74 nurses who were at the Datoe Binangkang Lolak Regional Hospital with inclusion criteria which had characteristics fulfilled by each member of the population that could be taken as the sample, while the exclusion criteria were characteristics of the members of the population that could not be taken as samples because various reasons.

Data collection techniques in this study using purposive sampling method through questionnaire distribution. Alternative answers from each respondent use a Likert scale, where this scale can be used to measure the attitude scale (Sekaran \& Bougie, 2013).

\section{RESULT AND DISCUSSIONS}

Table 1. Normality Test

\begin{tabular}{lllll}
\hline & No. & KSZ & Sig. & Information \\
\hline 1 & 0,061 & 0,200 & Normal \\
\hline
\end{tabular}

Based on the test table for the influence of work engagement and burnout on nurses' caring behavior, it can be concluded that the residual value is normally distributed, where the Kolmogorov-Smirnov value of the research variable obtained a significance value greater than 0.05 , so it can be said that the data is normally distributed.

Table 2. Multicollinearity Test

\begin{tabular}{clll}
\hline Variable & Tolerance & VIF & \multicolumn{1}{c}{ Information } \\
\hline work engagement & 0,896 & 1,116 & $\begin{array}{l}\text { Multicollinearity does not } \\
\text { occur }\end{array}$
\end{tabular}


burnout

0,896

1,116

Multicollinearity does not

occur

From the results of the multicollinearity test for each variable, the Tolerance value $>0.1$ and the VIF value $<10$, it can be concluded that there is no multicollinearity symptom.

Table 3. Heteroscedasticity test

\begin{tabular}{llll}
\hline \multicolumn{1}{c}{ Variable } & $t$-count & Sig. & \multicolumn{1}{c}{ Information } \\
\hline work engagement & $-1,370$ & 0,175 & $\begin{array}{l}\text { Heteroscedasticity does not } \\
\text { occur } \\
\text { burnout }\end{array}$ \\
\hline
\end{tabular}

Based on the table above, heteroscedasticity shows that the significant value of each variable is more than 0.05 , so it is said that heteroscedasticity does not occur.

In this study, the first simple regression test was used to test hypothesis 1 $(\mathrm{H} 1)$ on the effect of work engagement on burnout. Based on the table 4, the first model regression equation is as follows:

$I=-0,323 X+e$

Table 4 Results of Analysis Of Simple Regression

\begin{tabular}{|c|c|c|c|c|c|}
\hline \multirow[t]{2}{*}{ Model } & \multicolumn{2}{|c|}{$\begin{array}{l}\text { Unstandardized } \\
\text { Coefficients }\end{array}$} & \multirow{2}{*}{$\begin{array}{c}\text { Standardized } \\
\text { Coefficients } \\
\text { Beta }\end{array}$} & \multirow[t]{2}{*}{$t$} & \multirow[t]{2}{*}{ Sig. } \\
\hline & B & Std.Error & & & \\
\hline & 83, & 5,829 & & 14,404 & 0,000 \\
\hline $\begin{array}{l}\text { Work Engagement } \\
\text { Dependent Variable }\end{array}$ & $\begin{array}{r}-0,428 \\
\text { Burnout }\end{array}$ & 0,148 & $-0,323$ & $-2,894$ & 0,005 \\
\hline
\end{tabular}

The results of the regression equation show that a significant value is obtained at $0.005<0.05$ with a regression coefficient (b1) which is 0.323 which means that work engagement has a negative and significant effect on burnout.

The second test of multiple linear regressions is used to test hypothesis $2(\mathrm{H} 2)$ and hypothesis $3(\mathrm{H} 3)$, namely the effect of work engagement and burnout on nurses caring behavior.

Based on the table below, the second model regression equation is as follows:

$Y=0,293 X+-0,232 I+e$

The results of the regression equation show that a significant value is obtained of $0.012<0.05$ with a regression coefficient (b1) of 0.293 which means that Work Engagement has a positive and significant effect on Nurse Caring Behavior. 
The results of the regression equation can show that a significant value is obtained $0.044<0.05$ with a regression coefficient (b2) which is 0.232 which means that Burnout has a negative and significant effect on Nurse Caring Behavior.

So the results of the multiple linear regression test show that Work Engagement and Burnout have a significant effect on Nurse Caring Behavior.

Table 5 Results of Analysis Of Multiple Linear Regression Model Unstandardized Standardized $\mathrm{t}$ Sig. Coefficients Coefficients B Std. Error Beta

\begin{tabular}{lcccrc}
\hline Constant) & 86,559 & 11,111 & & 7,791 & 0,000 \\
Work Engagement & 0,391 & 0,151 & 0,293 & 2,589 & 0,012 \\
Burnout & $-0,233$ & 0,114 & $-0,232$ & -2.046 & 0,044 \\
Dependent Variable: Nurse & caring behavior & & & \\
\hline
\end{tabular}

The sobel test was conducted to test the significance of the indirect effect of Work Engagement on Nurse Caring Behavior through Burnout as an intervening variable as follows:

$t=\frac{\alpha b}{S \alpha b}=\frac{0,099}{0058}=1,706$

Based on these results, the $t$-value is 1.706 . The $t$-value is compared with the $\mathrm{t}$-table, where the $\mathrm{t}$ table is obtained based on a significance of $5 \%$ and df $(74-2)=72$, namely 1.669 . It can be seen that the calculated $t$ value is greater than $t$ table $(1.706>1.669)$. This shows that the $\mathrm{H} 4$ of this study, namely Burnout, is able to be an intervening variable between Work Engagement and Nurse Caring Behavior.

\section{CONCLUSION}

Based on the research results, it can be concluded that Work Engagement has a negative and significant effect on Burnout in nurses at the Datoe Binangkang Lolak Regional General Hospital. However, work engagement has a positive and significant effect on Caring Behavior Nurse at Datoe Binangkang Lolak Regional Hospital. On the other hand, Burnout has a negative and significant effect on the Caring Behavior of Nurses at Datoe Binangkang Lolak Regional Hospital. However, Burnout can mediate between Work Engagement and Nurse Caring Behavior in nurses at Datoe Binangkang Lolak Regional Hospital.

For future researchers, it is better to add variables of motivation, job stress or satisfaction. In addition, it can pay attention to the time of collecting data precisely when the nurse is not carrying out her nursing duties so that the nurse can focus on the research material, so that the research results have a better contribution to the hospital. 


\section{ACKNOWLEDGEMENT}

The researchers would like to thank the UMY Chancellor, the Master of Management Postgraduate Program and colleagues who have provided suggestions for the results of this research. The researcher also expressed his gratitude to the Director of RSUD Datoe Binangkang and his staff for their cooperation and contribution in this research.

\section{REFERENCES}

Bhatti, M. A., Mat, N., \& Juhari, A. S. (2018). Effects of job resources factors on nurses job performance (mediating role of work engagement). International journal of health care quality assurance.

Balasubramanian, S. A., \& Lathabhavan, R. (2017). Women's glass ceiling beliefs predict work engagement and burnout. Journal of Management Development.

Czerw, A., \& Grabowski, D. (2015). Work attitudes and work ethic as predictors of work engagement among Polish employees. Polish Psychological Bulletin, 46(4), 503-512.

Enns, C. L., \& Sawatzky, J. A. V. (2016). Emergency nurses' perspectives: Factors affecting caring. Journal of Emergency Nursing, 42(3), 240-245.

Ghozali, Imam. (2016). Aplikasi Analisis Multivariete Dengan Program IBM SPSS 23 (Edisi 8). Cetakan ke VIII. Semarang : Badan Penerbit Universitas Diponegoro.

Han, S. S., Han, J. W., \& Kim, Y. H. (2018). Effect of nurses' emotional labor on customer orientation and service delivery: the mediating effects of work engagement and burnout. Safety and Health at Work, 9(4), 441-446.

Jalilian, H., Shouroki, F. K., Azmoon, H., Rostamabadi, A., \& Choobineh, A. (2019). Relationship between job stress and fatigue based on job demand-control-support model in hospital nurses. International journal of preventive medicine, 10.

Kotze, M. (2018). How job resources and personal resources influence work engagement and burnout. African Journal of Economic and Management Studies, 9(2), 148-164. doi:10.1108/ajems-05-2017-0096

Lampert, B., \& Unterrainer, C. (2017). Detached Concern, me and my clientsProfessionals' emotion regulation, burnout, and patients' care quality at work. Research on emotion in organization: Emotions and identity. Bingley, UK: Emerald Group Publishing, 111-133.

Nightingale, S., Spiby, H., Sheen, K., \& Slade, P. (2018). The impact of emotional intelligence in health care professionals on caring behaviour towards patients in clinical and longterm care settings: Findings from an integrative review. International journal of nursing studies, 80, 106-117.

Rai, A., Ghosh, P., Chauhan, R., \& Mehta, N. K. (2017). Influence of job characteristics on engagement: does support at work act as moderator? International Journal of Sociology

and Social Policy.

Santhanam, N., \& Srinivas, S. (2019). Modeling the impact of employee engagement and happiness on burnout and turnover intention among blue-collar workers at a manufacturing company. Benchmarking: An International Journal. 
Sondenaa, E., Whittington, R., Lauvrud, C., \& Nonstad, K. (2015). Job stress, burnout and job satisfaction in staff working with people with intellectual disabilities: community and criminal justice care. Journal of Intellectual Disabilities and Offending Behaviour.

Sunaryo, H., Nirwanto, N., \& Manan, A. (2017). The Effect of Emotional and Spiritual Intelligence on Nurses' Burnout and Caring Behavior. International Journal of Academic Research in Bussines and Social Sciences, 7(12), 1211-1227.

Silver, J., Caleshu, C., Casson-Parkin, S., \& Ormond, K. (2018). Mindfulness among genetic counselors is associated with increased empathy and work engagement and decreased burnout and compassion fatigue. Journal of genetic counseling, 27(5), 1175-1186.

Sekaran., U \& Bougie,R. (2013). Edisi 5, Research Method For Business : A Skill Building Approach : john wiley@sons

Salmela-Aro, K., \& Upadyaya, K. (2018). Role of demands-resources in work engagement and burnout in different career stages. Journal of Vocational Behavior, 108, 190-200.

Tiara, T., \& Lestari, A. (2017). Perilaku Caring Perawat Dalam Meningkatkan Kepuasan Pasien Rawat Inap. Jurnal IImiah Keperawatan Sai Betik, 9(2), 115-119.

Tusa'diah, H., Tjahjono, H. K., Fauziyah, Palupi, M. (2017). Improvement of Employee Engagement Through Interaction Between Distributive Justice, Procedural Justice and Islamic Work Ethics. Proceedings of the 30th International Business Information Management Association (IBIMA), 2740-2745.

Vaksalla, A., \& Hashimah, I. (2015). How hope, personal growth initiative and meaning in life predict work engagement among nurses in Malaysia private hospitals. International Journal of Arts \& Sciences, 8(2), 321.

Zoraya, M., Tjahjono, H. K., Dewi, A., (2019). The Influence Of Work Engagement And Religiosity On Burnout Among Dentist At Primary Care Clinics. Ra Journal Of Applied Research. Volume: 05. Issn: 2394-6709. 